\title{
Neurologic and cognitive outcomes associated with the clinical use of xenon: a systematic review and meta-analysis of randomized- controlled trials
}

\section{Effets neurologiques et cognitifs associés à l'utilisation clinique du xénon : revue systématique et méta-analyse des essais randomisés contrôlés}

\author{
Lawrence Siu-Chun Law, MD - Elaine Ah-Gi Lo, PharmD, BCPS, BCGP • \\ Caspar Chi-Chung Chan, MD - Tong Joo Gan, MD, MBA, FRCA, MHS, LiAc
}

Received: 11 August 2017/Revised: 18 April 2018/Accepted: 25 May 2018/Published online: 1 June 2018

(C) Canadian Anesthesiologists' Society 2018

\begin{abstract}
Background Xenon has been shown to have positive neurologic effects in various pre-clinical models. This study systematically reviewed the randomized-controlled trials (RCTs) investigating neurologic and cognitive outcomes associated with the clinical use of xenon.

Methods We searched PubMed, CENTRAL, EMBASE, CINAHL, elibrary.ru (for Russian studies), Google Scholar (for Russian studies), and Wanfang (for Chinese studies) for appropriate RCTs comparing neurologic or cognitive outcomes after clinical use of xenon with control treatment or with other anesthetic agents.

Results Seventeen RCTs met the inclusion criteria. Two studies investigated the effects of xenon plus therapeutic hypothermia to treat neonatal asphyxia or out-of-hospital cardiac arrest. Compared with therapeutic hypothermia alone, xenon and therapeutic hypothermia reduced cerebral
\end{abstract}

Electronic supplementary materialThe online version of this article (https://doi.org/10.1007/s12630-018-1163-6) contains supplementary material, which is available to authorized users.

Lawrence Siu-Chun Law and Elaine Ah-Gi Lo-contributed equally and considered as co-first authors.

L. S.-C. Law, MD - E. A.-G. Lo, PharmD, BCPS, BCGP

National University Hospital, Singapore, Singapore

C. C.-C. Chan, MD

North-Western State Medical University, Petersburg, Russia

T. J. Gan, MD, MBA, FRCA, MHS, LiAc ( $\square)$

Department of Anesthesiology, Stony Brook Medicine, HSC

Level 4, Rm 060, Stony Brook, NY 11794-8480, USA

e-mail: tong.gan@stonybrookmedicine.edu white matter abnormalities after cardiac arrest but had no effect on neurocognitive outcome and mortality. Xenon had no added value when used to treat neonatal asphyxia. Thirteen RCTs compared neurocognitive effects of xenon with other anesthetic agents in surgical patients. While xenon may be associated with improved short-term (< three hours) cognitive outcome, no medium-term (six hours to three months) advantage was observed, and longer-term data are lacking. No differences in biochemical (S-100 $\beta$, neuron-specific enolase) and neuropsychologic (attentional performance) outcomes were found with xenon compared with other anesthetic drugs. Finally, two studies suggest that brief, intermittent administration of sub-anesthetic doses of xenon to patients during the acute phase of substance withdrawal may improve neurocognitive outcomes. Conclusions Despite promising pre-clinical results, the evidence for positive clinical neurologic and cognitive outcomes associated with xenon administration is modest. Nevertheless, there is some evidence to suggest that xenon may be associated with better neurologic outcomes compared with the standard of care therapy in certain specific clinical situations. More clinical trials are needed to determine any potential benefit linked to xenon administration.

\section{Résumé}

Contexte Différents modèles précliniques ont montré que le xénon a des effets neurologiques positifs. Cette étude a systématiquement passé en revue les essais cliniques randomisés (ECR) étudiant les effets neurologiques et cognitifs associés à l'utilisation clinique du xénon.

Méthodes Nous avons recherché les ECR appropriés comparant les effets neurologiques ou cognitifs de 
l'utilisation clinique du xénon à ceux d'un traitement témoin ou d'autres agents anesthésiques dans les bases de données PubMed, CENTRAL, EMBASE, MEDLINE, elibrary.ru et Google Scholar (pour les études russes) et Wanfang (pour les études chinoises).

Résultats Dix-sept ECR ont correspondu aux critères d'inclusion. Deux études ont recherché les effets du xénon et de l'hypothermie thérapeutique dans le traitement de l'asphyxie néonatale ou de l'arrêt cardiaque hors de l'hôpital. Comparativement à l'hypothermie thérapeutique seule, le xénon associé à l'hypothermie thérapeutique a réduit les anomalies de la substance blanche cérébrale après un arrêt cardiaque, mais n'a eu aucun effet sur l'évolution neurocognitive et la mortalité. Le xénon n'a apporté aucune valeur ajoutée au traitement de l'asphyxie néonatale. Treize ECR ont comparé les effets neurocognitifs du xénon à ceux d'autres agents anesthésiques chez des patients chirurgicaux. Bien que le xénon puisse être associé $\grave{a}$ une amélioration à court terme $(<$ trois heures) des fonctions cognitives, aucun avantage à moyen terme (six heures à trois mois) n'a été observé et il n'existe pas de données à plus long terme. Aucune différence sur des critères biochimiques (énolase spécifique des neurones, $S-100 \beta$ ) et neuropsychologiques (performance de l'attention) n'a été constatée avec le xénon par rapport aux autres agents anesthésiques. Enfin, deux études suggèrent qu'une administration brève et intermittente de doses infra-anesthésiques de xénon à des patients en phase aiguë de sevrage de substance peut améliorer l'évolution neurocognitive.

Conclusions Malgré des résultats précliniques prometteurs, les données probantes d'effets cliniques neurologiques et cognitifs positifs associés à l'administration de xénon restent modestes. Néanmoins, il existe quelques données indiquant que le xénon pourrait être associé à une meilleure évolution neurologique par rapport aux traitements de référence dans certaines situations cliniques particulières. D'autres essais cliniques sont nécessaires pour déterminer un éventuel avantage lié à l'administration de xénon.

Xenon is a noble gas with potential benefits when used for general anesthesia. ${ }^{1,2}$ Neurologic and cognitive outcomes associated with xenon administration have been tested in various pre-clinical in vitro and in vivo models ${ }^{3,4}$ (Table 1) concerned with neurotoxicity, ${ }^{3-9}$ neonatal asphyxia, ${ }^{10-14}$ cardiac arrest, ${ }^{15-17}$ and ischemic ${ }^{18-23}$ and traumatic ${ }^{24-26}$ brain injury. Most of the pre-clinical investigations showed positive central nervous system (CNS)-related outcomes. For instance, xenon has been shown to prevent isofluraneinduced neurotoxicity and neuroapoptosis in rats. ${ }^{4,5,9}$ Xenon has also been shown to improve outcomes following neonatal asphyxia ${ }^{10-14}$ and cardiac arrest ${ }^{17}$ when combined with conventional therapeutic hypothermia in rodent and porcine models.

The positive CNS-related effects of xenon are thought to be conferred mainly through antagonizing N-methyl-D-aspartate (NMDA) receptors at the glycine site, thus reducing the neuronal injury caused by excessive glutamate-induced stimulation in the early phase of reperfusion injury. ${ }^{22,25,27} \mathrm{It}$ may also reduce apoptosis by activating anti-apoptotic factors in the later phase of reperfusion injury. ${ }^{4}$ Other postulated mechanisms include the modulation of neuroinflammation, ${ }^{28,29}$ potassium channels, ${ }^{30,31}$ and hypoxia-inducible factor $1 \alpha^{32}$ When used as an anesthetic, xenon has been associated with a more stable intraoperative blood pressure than other inhaled agents or total intravenous anesthesia using propofol. ${ }^{1}$ As such, xenon's hemodynamic stability may be an underlying mechanism for its protection of neural, cardiac, and renal function. ${ }^{33}$

Despite these encouraging results, clinical data are needed to confirm the neurologic and cognitive benefits of xenon. Two randomized-controlled trials ${ }^{34,35}$ (RCTs) investigated the neuroprotective effects of xenon when used as therapeutic treatment following neonatal asphyxia or cardiac arrest. Several RCTs have assessed the effects of xenon in other clinical settings, for instance, general anesthesia or the acute phase of substance abuse. ${ }^{36-39}$ Nevertheless, there is no systematic review or meta-analysis of these clinical studies. This article is the first systematic review of RCTs investigating the potential neurologic and cognitive benefits associated with xenon administered to human patients.

\section{Methods}

\section{Search strategy}

This study conformed to the Preferred Reporting Items for Systematic Reviews and Meta-analyses (PRISMA) statement. ${ }^{40} \mathrm{We}$ searched for RCTs that compared xenon with any type of control treatment for influence on neurologic or cognitive outcomes of clinical relevance including radiologic or biochemical effects. We used the search term "xenon AND (neuroprotect* OR neurocognit* OR cognit*)" in PubMed, CENTRAL, EMBASE, and CINAHL. We searched for Russian language publications with the search term "ксенон" in elibrary.ru and "ксенон [хеnon] AND (нейропротекции [neuroprotection] OR неврологический [neurologic] OR познавательный [cognitive])" in Google Scholar, as we expected a considerable number of Russian studies. ${ }^{41} \mathrm{We}$ searched for Chinese language publications with the search term “氙 [xenon] and (神經 [neuro] or 認知 [cognitive])" in Wanfang [萬方數據]. We did not impose restrictions on the year of publication or 


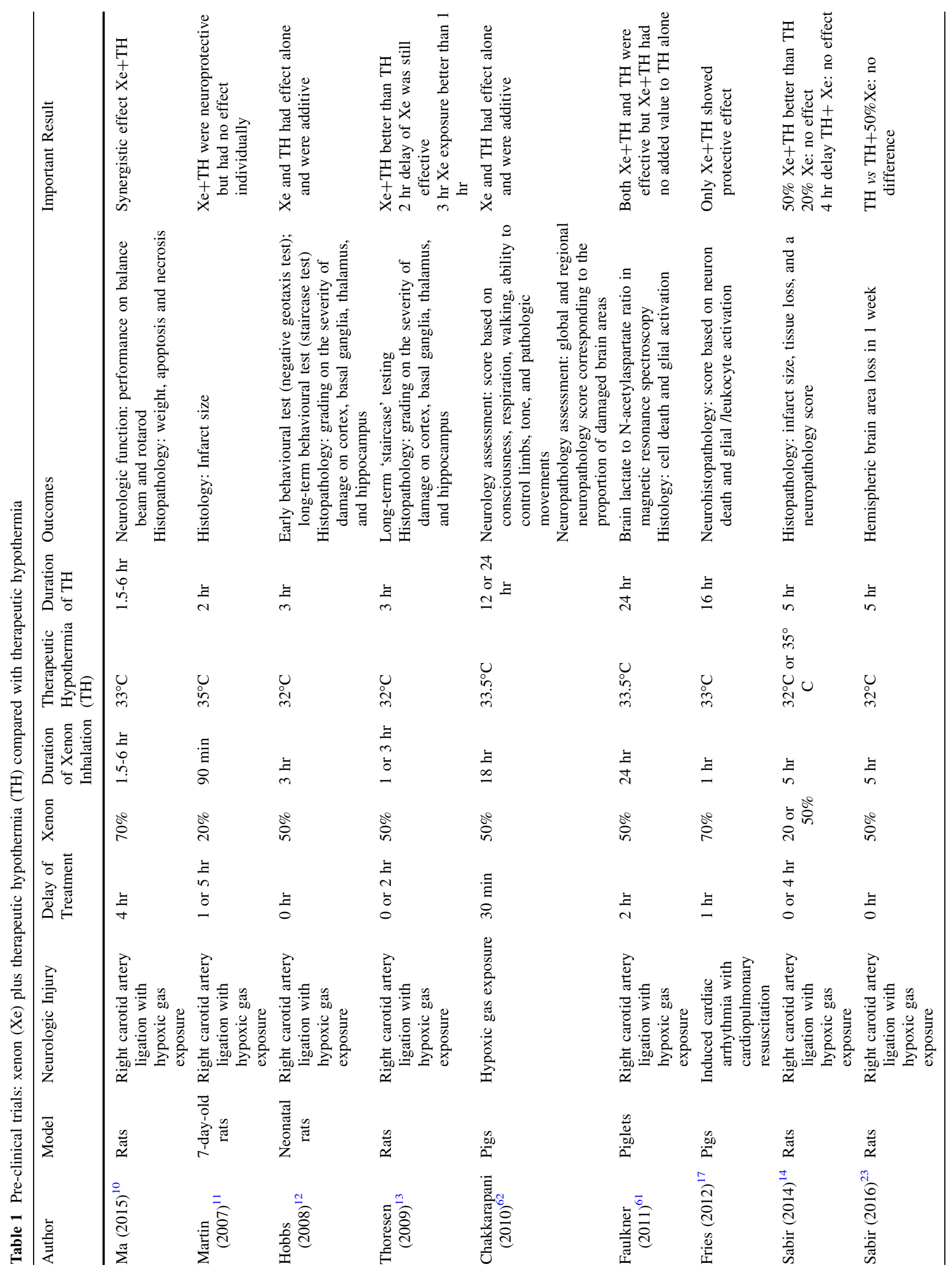


language. We only included human studies and excluded all non-RCTs. The latest search was done in February 2018. The two co-first authors (L.L. and E.L.) independently searched and assessed the English and Chinese literature for eligibility. The first and third authors (L.L. and C.C.) independently searched for the papers written in Russian. Conference abstracts published prior to 2016 were excluded.

\section{Data extraction}

Included studies were categorized according to clinical scenario, namely, neonatal asphyxia, cardiac arrest, general anesthesia, and substance addiction. Meta-analysis was conducted for the following outcomes: plasma levels of S$100 \beta$ (ng. $\mathrm{L}^{-1}$; biomarker for glial injuries and the integrity of blood-brain barrier) and neuron-specific enolase (NSE, $\mathrm{g} \cdot \mathrm{L}^{-1}$; biomarker for neuronal injuries) and tests for cognitive performance associated with xenon anesthesia versus other anesthetic agents. The number of studies involving neonatal asphyxia, cardiac arrest, and substance addiction was limited so the results from these studies were systematically reviewed and descriptively summarized.

\section{Quality assessment}

We assessed the methodologic quality of included RCTs with the Jadad score ${ }^{42}$ and bias risk using the Cochrane tool for risk of bias. ${ }^{43}$ Results of meta-analyses were graded for quality of evidence using the Grading of Recommendations, Assessment, Development, and Evaluations (GRADE) Working Group system. ${ }^{44}$

\section{Statistical analyses}

Meta-analysis was conducted with Review Manager 5.3 (Cochrane Collaboration, Copenhagen). Standard deviation (SD) was estimated by the following formulae: $S D=$ $S E M \sqrt{N} ; S E M=\frac{95 \% C I}{1.96}$ (SEM, standard error of mean; $95 \%$ confidence interval [CI]). If SD could not be determined, we substituted the missing SD with the pooled SD of other studies by: $\sqrt{\frac{\sum N S D^{2}}{\sum N}}$. For continuous variables, standardized mean differences ${ }^{45}$ were compared with the inverse variance method. Because of the limited number of studies, we used a random effect model with adjustments according to the Satterthwaite approach $^{46}$ for all comparisons regardless of the heterogeneity. For all comparisons, statistical significance was set at $P<0.05$ (two sided) and 95\% CIs were reported. Due to the limited number of studies, sensitivity and subgroup analyses were not conducted.

\section{Results}

Study selection

Of the 1,064 studies initially identified, $17 \mathrm{RCTs}^{34-39,47-56}$ met the inclusion criteria (Fig. 1). $\operatorname{Ten}^{34,35,38,39,51-55,57,58}$ were published in English and seven ${ }^{36,37,47-50,56}$ in Russian or Ukrainian. No study published in Chinese met the inclusion criteria. Characteristics are presented in Table 2.

One $\mathrm{RCT}^{34}$ examined the effect of xenon plus therapeutic hypothermia in out-of-hospital cardiac arrest patients. One $\mathrm{RCT}^{35}$ investigated the effect of xenon plus therapeutic hypothermia in birth-related neonatal asphyxia. Thirteen RCTs ${ }^{38,39,47-50,52-58}$ compared xenon anesthesia with other inhaled agents or total intravenous anesthesia (propofol). Two studies ${ }^{36,37}$ investigated the effect of xenon as an adjuvant therapy during the withdrawal phase of addictive substances. Reasons for exclusion of the other identified studies are summarized in Fig. 1. Table 2 summarizes the major results of included studies.

Xenon plus therapeutic hypothermia treatment for outof-hospital cardiac arrest

Laitio et ll $^{34}$ randomized 110 out-of-hospital cardiac arrest patients presenting initially with ventricular fibrillation or pulseless ventricular tachycardia into either therapeutic hypothermia treatment $\left(33.5^{\circ} \mathrm{C}\right.$ for $\left.24 \mathrm{hr}\right)$ or inhaled $40 \%$ xenon plus therapeutic hypothermia treatment. The investigators performed diffusion tensor magnetic resonance imaging at 36-52 hr after cardiac arrest to evaluate fractional anisotropy as the primary outcome. Fractional anisotropy was used to estimate the cerebral white matter abnormality and a greater value is believed to be predictive of a better neurocognitive outcome after cardiac arrest. ${ }^{59}$ The raw and adjusted mean global fractional anisotropy values were greater in the xenon group than in the control group.

Secondary endpoints including mortality rate and neurocognitive outcome were not significantly different between the xenon and control groups at six months. Nevertheless, the absolute reduction in mortality rate in the xenon group compared with the control group may have been clinically (though not statistically) significant $(27.3 \%$ vs $34.5 \%, P=0.053)$

Xenon plus therapeutic hypothermia for neonatal asphyxia

Azzopardi et al. ${ }^{35}$ compared the effect of inhaled xenon (30\% for $24 \mathrm{hr}$ ) plus hypothermia $\left(33.5^{\circ} \mathrm{C}\right.$ for $\left.72 \mathrm{hr}\right)$ with hypothermia alone in 92 full-term birth-asphyxiated neonates. The investigators used magnetic resonance spectroscopy (to measure lactate to $\mathrm{N}$-acetyl aspartate ratio in the thalamus) 


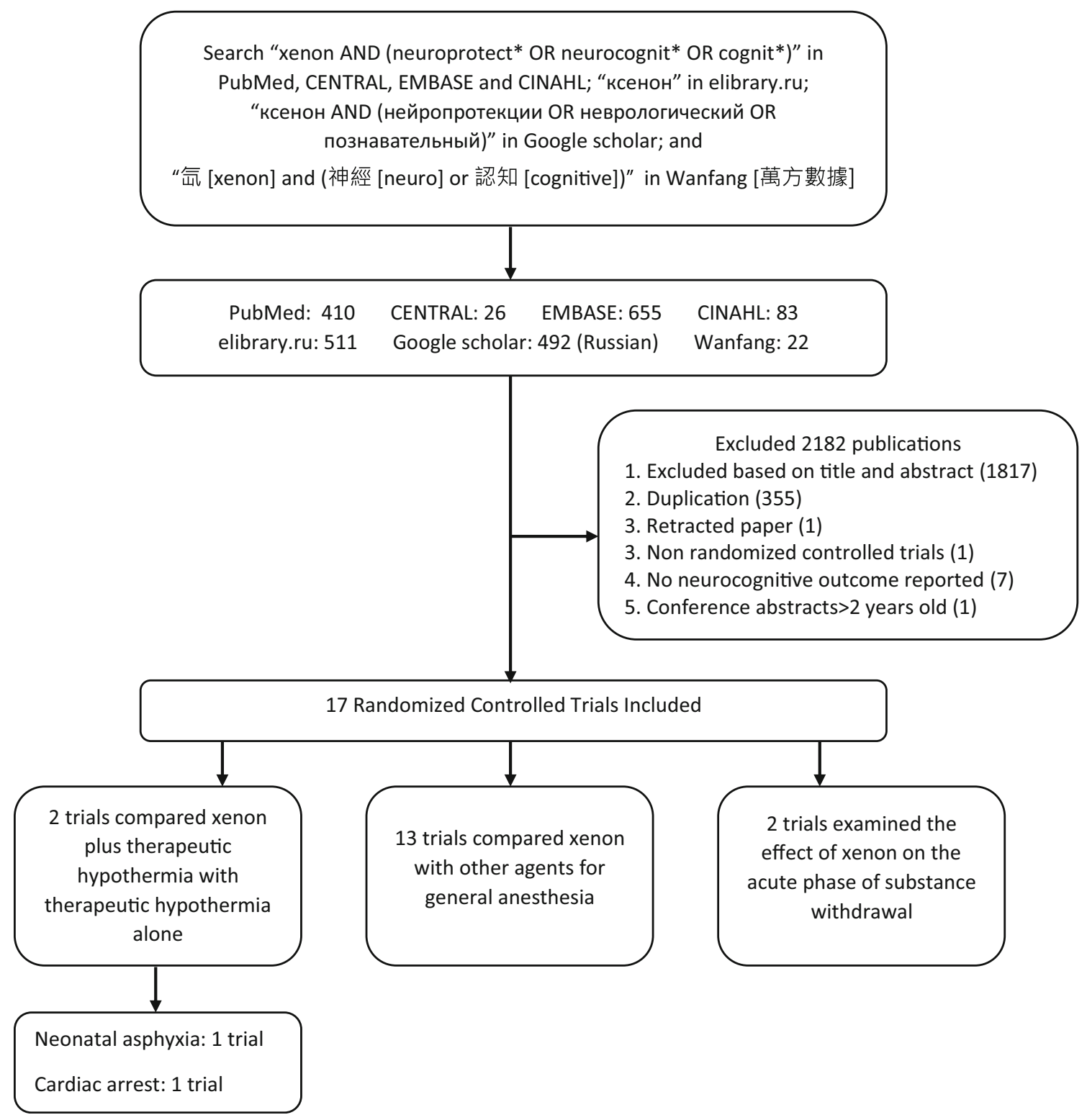

Fig. 1 Flow chart for included studies

and diffusion tensor magnetic resonance imaging (to evaluate the fractional anisotropy in the posterior limb of the internal capsule) at approximately six days after birth. No differences were observed between the two treatment groups. Similarly, all secondary outcome variables including the maximum Thompson Hypoxic Ischemic Encephalopathy Score in the first week of life, neurologic assessment at discharge, mortality rate, incidence of seizures, intracranial hemorrhage, and length of hospital stay were also unaffected.

Cognitive outcomes after general anesthesia

The included studies comprised a wide range of surgical procedures including coronary artery bypass, knee replacement, and brain surgery, as summarized in Table 2 . Two studies ${ }^{39,54}$ assessed attentional performance at 6-12 and 66-72 hr after surgery. Meta-analysis showed no difference in patients anesthetized with xenon compared with other volatile agents (sevoflurane or desflurane; see Electronic Supplementary Material (ESM) - Supplementary Figs. 1 and 2). The quality of evidence was high according to GRADE. Five studies ${ }^{38,52-55}$ compared other short-term postoperative cognitive outcomes between xenon (50-70\%) and other anesthetic drugs (1.1-1.4\% sevoflurane, ${ }^{38,54,55}$ $0.6 \%$ isoflurane, ${ }^{52}$ or $3-5 \mathrm{mg} \mathrm{kg}^{-1} \mathrm{~h}^{-1}$ propofol). ${ }^{53}$ Various cognitive assessments were made using the "Short Orientation Memory Concentration Test", "Syndrome Short Test", "Recall of Digit Span", "Digit Symbol Substitution 
Table 2 Characteristics and important outcomes of the included randomized-controlled trials

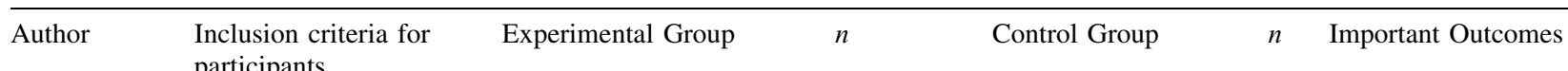
participants

Cardiac arrest

Laitio

$(2016)^{34}$
Out-of-hospital cardiac arrest, 24-76 yr old $\geq 40 \%$ xenon (mean $48.2 \% \quad 55$

$\pm 3.8 \%)$ with $\mathrm{TH}\left(33^{\circ} \mathrm{C}\right)$

for $24 \mathrm{hr}$

Neonatal asphyxia

\section{Azzopardi Infants \\ $(2016)^{35} \quad 1$. Born in 36-43 weeks of gestational age \\ 2. Moderate to severe encephalopathy with abnormal clinical signs and EEG background activity $\geq 30 \mathrm{~min}$ \\ 3. Apgar score $\leq 5$ at 10 min, continued need for resuscitation at 10 min, or acidosis within $1 \mathrm{hr}$}

General anesthesia (English)

\section{Al Tmimi \\ CABG patients} $(2015)^{38}$

$\begin{array}{cl}\text { Bronco } & \text { Adults undergoing } \\ (2010)^{55} & \begin{array}{l}\text { elective non-cardiac } \\ \text { surgery }\end{array}\end{array}$

Cremer

$(2011)^{54}$

Adults 65-75 yr old, undergoing elective surgery (trauma, orthopedics, ENT, gynecology, neurosurgery, abdominal surgery)

TH alone

55

1. Xenon plus $\mathrm{TH}$ resulted in less white matter damage (fractional anisotrophy of diffusion tensor MRI)

2. There was a trend that the mortality rate of the xenon group (27.3\%) was lower than that of the control group $(34.5 \%)$ at 6 months (adjusted hazard ratio 0.49 [95\% CI, 0.23 to 1.01], $P=0.053$ )

3. No difference in neurocognitive outcomes at 6 months

$30 \%$ inhaled xenon for $24 \quad 46$ hr with cooling to rectal temperature of $33.5^{\circ} \mathrm{C}$ for $72 \mathrm{hr}$
21
Cooling to rectal temperature of $33.5^{\circ} \mathrm{C}$ for $72 \mathrm{hr}$

$60 \%$ xenon anesthesia

$60 \%$ xenon anesthesia

$1.1-1.4 \%$ sevoflurane anesthesia

1.1-1.4\% sevoflurane anesthesia

$1.4 \%$ sevoflurane anesthesia
46 No difference in (1) lactate to $\mathrm{N}$-acetyl aspartate ratio in thalamus, (2) fractional anisotrophy in the posterior limb of the internal capsule, (3) maximum Thompson hypoxic ischemic encephalopathy score in the 1 st week of life, and (4) neurologic assessment upon discharge

30

1. Patients receiving xenon anesthesia had a lower risk for postoperative delirium

2. No difference in MMSE on POD 3 and upon discharge

3. No difference in serum S- $100 \beta$ and inflammatory markers

Better early (30-60 min) postoperative cognitive recovery after xenon anesthesia (Short Orientation Memory Concentration Test)

20 No difference in postoperative cognitive function at 6-12 and 66$72 \mathrm{hr}$ (Test of Attentional Performance and several Paper-Pencil-Tests) 
Table 2 continued

\begin{tabular}{|c|c|c|c|c|c|c|}
\hline Author & $\begin{array}{l}\text { Inclusion criteria for } \\
\text { participants }\end{array}$ & Experimental Group & $n$ & Control Group & $n$ & Important Outcomes \\
\hline $\begin{array}{l}\text { Coburn } \\
(2007)^{39}\end{array}$ & $\begin{array}{l}\text { Adults } 65-75 \text { yr old, } \\
\text { undergoing elective } \\
\text { general surgery } \\
\text { (trauma, head/neck/ } \\
\text { ear, gynecology, } \\
\text { urology) }\end{array}$ & $60 \%$ xenon anesthesia & 18 & $\begin{array}{l}5.2-5.5 \% \text { desflurane } \\
\text { anesthesia }\end{array}$ & 20 & $\begin{array}{l}\text { No difference in } \\
\text { postoperative cognitive } \\
\text { function at } 6-12 \text { and } 66- \\
72 \mathrm{hr} \text { (Attentional } \\
\text { Performance Test) }\end{array}$ \\
\hline $\begin{array}{l}\text { Coburn } \\
(2018)^{57}\end{array}$ & $\begin{array}{l}\text { Elderly } \geq 75 \text { yr old } \\
\text { undergoing hip } \\
\text { fracture surgery }\end{array}$ & $60 \%$ xenon anesthesia & 124 & $\begin{array}{l}1.1-1.4 \% \text { sevoflurane } \\
\text { anesthesia }\end{array}$ & 132 & $\begin{array}{l}\text { No difference in } \\
\text { postoperative delirium in } \\
\text { both early (POD 0-4) and } \\
\text { late ( } \geq \text { POD 5) } \\
\text { postoperative periods }\end{array}$ \\
\hline $\begin{array}{l}\text { Devroe } \\
(2017)^{58}\end{array}$ & $\begin{array}{l}\text { Children }<4 \text { yr old } \\
\text { undergoing } \\
\text { interventional or } \\
\text { diagnostic cardiac } \\
\text { catheterization }\end{array}$ & $\begin{array}{l}50-65 \% \text { xenon and titrating } \\
\text { sevoflurane according to } \\
\text { BIS target: } 40-60\end{array}$ & 20 & $\begin{array}{l}\text { Sevoflurane only, } \\
\text { titrating sevoflurane } \\
\text { according to BIS } \\
\text { target: } 40-60\end{array}$ & 20 & $\begin{array}{l}\text { 1. Xenon reduced } \\
\text { emergence agitation but } \\
\text { not delirium } \\
\text { 2. Patient who received } \\
\text { xenon had a shorter } \\
\text { period of low cerebral } \\
\text { saturation } \\
\text { intraoperatively } \\
\text { 3. No difference in } S-100 \beta\end{array}$ \\
\hline $\begin{array}{l}\text { Rasmussen } \\
(2006)^{53}\end{array}$ & $\begin{array}{l}\text { Adults } \geq 60 \text { yr old, } \\
\text { undergoing elective } \\
\text { knee replacement } \\
\text { under spinal anesthesia }\end{array}$ & 50-70\% xenon anesthesia & 21 & $\begin{array}{l}\text { Total intravenous } \\
\text { anesthesia with } \\
\text { propofol 3-5 } \\
\mathrm{mg} \cdot \mathrm{kg}^{-1} \cdot \mathrm{hr}^{-1}\end{array}$ & 18 & $\begin{array}{l}\text { No difference in cognitive } \\
\text { function at 3-5 days and } \\
10-14 \text { months (Visual } \\
\text { Verbal Learning Test, } \\
\text { Concept Shifting Test, } \\
\text { Stroop Color Word } \\
\text { Interference Test, Letter } \\
\text { Digit Coding Test) }\end{array}$ \\
\hline $\begin{array}{l}\text { Stuttmann } \\
(2010)^{52}\end{array}$ & $\begin{array}{l}\text { Adults undergoing } \\
\text { elective } \\
\text { thyroidectomy, } \\
\text { augmentation or } \\
\text { reduction } \\
\text { mammaplasty, } \\
\text { liposuction for obesity, } \\
\text { and knee arthroscopy }\end{array}$ & $63 \%$ xenon anesthesia & 31 & $\begin{array}{l}0.6 \% \text { isoflurane } \\
\text { anesthesia }\end{array}$ & 30 & $\begin{array}{l}\text { Xenon anesthesia had a } \\
\text { better recovery of early } \\
\text { postoperative cognitive } \\
\text { function (Syndrome } \\
\text { Short Test and Recovery } \\
\text { Index) at } 60 \text { and } 180 \text { min } \\
\text { post extubation }\end{array}$ \\
\hline \multicolumn{7}{|c|}{ General anesthesia (Russian) } \\
\hline $\begin{array}{l}\text { Bagaev } \\
\quad(2015)^{47}\end{array}$ & Children 5 to $17 \mathrm{yr}$ & $\begin{array}{l}60-65 \% \text { xenon anesthesia } \\
\text { with } \mathrm{Xe}-\mathrm{O}_{2}\end{array}$ & 22 & $\begin{array}{l}2.5 \% \text { sevoflurane } \\
\text { anesthesia }\end{array}$ & 20 & $\begin{array}{l}\text { No difference in serum S- } \\
100 \beta \text { and brain-derived } \\
\text { neurotrophic factor }\end{array}$ \\
\hline $\begin{array}{l}\text { Mizikov } \\
\text { (Мизиков) } \\
(2013)^{49}\end{array}$ & Neurosurgery & $\begin{array}{l}\text { Group 1: xenon alone [0.8- } \\
\text { 1.0 MAC] } \\
\text { Group 2: } 50 \% \text { xenon with } \\
\text { isoflurane [0.2-0.3 MAC] } \\
\text { Group 3: } 50 \% \text { xenon with } \\
\text { sevoflurane [0.2-0.3 } \\
\text { MAC] }\end{array}$ & $\begin{array}{l}\text { Group 1: } 12 \\
\text { Group 2: } 20 \\
\text { Group 3: } 20\end{array}$ & $\begin{array}{c}\text { Sevoflurane alone } \\
{[0.8-1.0 \mathrm{MAC}]}\end{array}$ & 20 & $\begin{array}{l}\text { No difference in serum S- } \\
100 \beta \text { and neuron-specific } \\
\text { enolase }\end{array}$ \\
\hline $\begin{array}{l}\text { Grantovna } \\
\text { (Петросян) } \\
(2014)^{50}\end{array}$ & Neurosurgery & $\begin{array}{l}50 \% \text { xenon with } \\
\text { sevoflurane }[0.2-0.3 \\
\text { MAC }]\end{array}$ & 36 & $\begin{array}{c}\text { Sevoflurane alone } \\
{[0.8-1.0 \mathrm{MAC}]}\end{array}$ & 41 & $\begin{array}{l}\text { Xenon anesthesia was } \\
\text { associated with lower } \\
\text { serum neuron-specific } \\
\text { enolase in patients with } \\
\text { covexital tumours but } \\
\text { higher serum } S-100 \beta \text { in } \\
\text { patients with tumours } \\
\text { located in base of brain }\end{array}$ \\
\hline
\end{tabular}


Table 2 continued

\begin{tabular}{|c|c|c|c|c|c|c|}
\hline Author & $\begin{array}{l}\text { Inclusion criteria for } \\
\text { participants }\end{array}$ & Experimental Group & $n$ & Control Group & $n$ & Important Outcomes \\
\hline $\begin{array}{l}\text { Shishneva } \\
\text { (Шишнева) } \\
(2009)^{56}\end{array}$ & $\begin{array}{l}\text { CABG surgery patients, } \\
53-67 \text { yr old }\end{array}$ & Group 1: xenon anesthesia & 20 & $\begin{array}{l}\text { Group 4: traditional } \\
\text { operation. (group 2- } \\
3 \text { not relevant) }\end{array}$ & 38 & $\begin{array}{l}\text { Patients received xenon } \\
\text { anesthesia had better } \\
\text { cognitive function and } \\
\text { psycho-emotive state }\end{array}$ \\
\hline $\begin{array}{l}\text { Shishneva } \\
\text { (Шишнева) } \\
(2010)^{48}\end{array}$ & CABG surgery patients & $\begin{array}{l}\text { Group } 2(n=30): 60 \% \\
\quad \text { xenon anesthesia }\end{array}$ & 30 & $\begin{array}{l}\text { Group 1: traditional } \\
\text { operation (group } 3 \\
\text { not relevant) }\end{array}$ & 29 & $\begin{array}{l}\text { Serum } S-100 \beta \text { was lower in } \\
\text { the xenon group before } \\
\text { removing the aortic } \\
\text { clamp but no difference } \\
\text { on POD } 1 \text { and POD } 2\end{array}$ \\
\hline \multicolumn{7}{|c|}{ Withdrawal from addictive substance } \\
\hline $\begin{array}{l}\text { Striepetova } \\
(2014)^{37} \\
{[\text { Ukraine] }}\end{array}$ & Alcohol addiction & $\begin{array}{l}\text { Standard treatment }+ \\
\text { xenon inhalation therapy } \\
(25-30 \% \text { for } 10-15 \mathrm{~min} \\
\text { once a day) }\end{array}$ & 67 & $\begin{array}{l}\text { Standard therapy: } \\
\text { benzodiazepines, } \\
\text { anesthetics } \\
\text { (propofol), } \\
\text { anxiolytics } \\
\text { (hydroxyzine), } \\
\text { neuroleptics, and } \\
\text { symptomatic } \\
\text { treatments }\end{array}$ & 70 & $\begin{array}{l}\text { 1. Patients in the xenon } \\
\text { group had higher scores } \\
\text { in MMSE and Wechsler } \\
\text { Memory Test on } 2^{\text {nd }}-6^{\text {th }} \\
\text { days of ICU stay } \\
\text { 2. The duration of delirium } \\
\text { was shorter in the xenon } \\
\text { group }\end{array}$ \\
\hline $\begin{array}{l}\text { Tzigankov } \\
\text { (Цыганков) } \\
(2013)^{36} \\
\text { [Russian] }\end{array}$ & $\begin{array}{l}\text { Acute alcohol or opioid } \\
\text { withdrawal }\end{array}$ & $\begin{array}{l}\text { Standard treatment }+ \\
\text { xenon inhalation }\left(\mathrm{Xe}: \mathrm{O}_{2}\right. \\
=1: 2): 3 \text { inhalations in } \\
\text { the first } 2 \text { days of } \mathrm{ICU} \\
\text { admission, then } 1-2 \\
\text { inhalations per day for } 3 \\
\text { days }\end{array}$ & 60 & $\begin{array}{l}\text { Standard treatment: } \\
\text { antipsychotics, } \\
\text { tranquilizers, } \\
\text { vasopressors, } \\
\text { antiplatelet agents, } \\
\text { vitamins, glucose, } \\
\text { amino acids }\end{array}$ & 60 & $\begin{array}{l}\text { 1. More patients in the } \\
\text { xenon group had an } \\
\text { improvement in } \\
\text { neuropsychologic } \\
\text { assessments (memory, } \\
\text { abstraction, etc.) in 5-6 } \\
\text { days } \\
\text { 2. Rheoencephalography (a } \\
\text { non-invasive technique } \\
\text { that evaluates cerebral } \\
\text { blood flow): xenon group } \\
\text { had a lower vascular tone } \\
\text { and higher pulse wave } \\
\text { amplitude, which were } \\
\text { signs of cerebral } \\
\text { hemodynamic } \\
\text { normalization } \\
\text { 3. EEG: the xenon group } \\
\text { had less pathologic } \\
\text { waves }\end{array}$ \\
\hline
\end{tabular}

$\mathrm{BIS}=$ bispectral index CABG = coronary artery bypass graft $\mathrm{CI}=$ confidence interval; $\mathrm{EEG}=$ electroencephalography; ENT $=$ ear, nose, and throat; $\mathrm{ICU}=$ intensive care unit; $\mathrm{MAC}=$ minimal alveolar concentration; $\mathrm{MMSE}=$ Mini-Mental State Examination; MRI = magnetic resonance imaging; $\mathrm{POD}=$ postoperative day; $\mathrm{TH}=$ therapeutic hypothermia

Test", "Trail Making Test", and "Mini-Mental State Examination". Nevertheless, these outcomes were too heterogeneous for meta-analysis. While xenon anesthesia was associated with improved cognitive function in the early postoperative period (30-180 min), ${ }^{52,55}$ such benefit was not maintained after six hours.

The results for postoperative delirium were mixed. The incidence of delirium was found to be lower after xenon anesthesia for coronary artery bypass surgery ${ }^{38}$ but not hip fracture surgery ${ }^{57}$ in adults. Xenon as an adjuvant to sevoflurane anesthesia reduced emergence agitation but not delirium in children ( $<$ four years old) undergoing interventional or diagnostic cardiac catheterization. ${ }^{58}$
Biomarkers for glial and neuronal injuries

Six studies ${ }^{38,47-50,58}$ measured S-100 $\beta$ and two studies ${ }^{49,50}$ measured NSE plasma levels. Meta-analysis showed that xenon (either $60 \%$ xenon alone $e^{38,47,48}$ or a combination ${ }^{49,50}$ of xenon [50\%] and sevoflurane (0.2-0.3 minimal alveolar concentration [MAC]) had no significant effect on the serum levels of either S-100 $\beta$ or NSE compared with sevoflurane (0.8-1.1 MAC) (Figs. 2 and 3). The quality of evidence was moderate according to GRADE. Devroe et al. $^{58}$ did not report the exact levels of S-100 $\beta$ (and therefore were not included in the meta-analysis), but they also found that xenon had no effect on S-100 $\beta$ levels. 
Bagaev et $a l^{47}$ also reported that serum levels of brainderived neurotrophic factor were not significantly different in children (5-17 yr old) anesthetized with either xenon $(65 \%)$ or sevoflurane $(2.5 \%)$.

\section{Withdrawal from addictive substances}

Striepetova et al. $^{37}$ assessed 137 patients admitted to the ICU for the acute phase of alcohol detoxification. Seventy patients underwent the standard therapy, which included sedation (with benzodiazepines [diazepam], anesthetics [propofol], anxiolytics [hydroxyzine]) or neuroleptics. Sixty-seven patients received $25-30 \%$ xenon for $10-15 \mathrm{~min}$ once a day in addition to the standard therapy. Patients in the xenon plus standard therapy group had higher scores on the Mini-Mental State Examination and Wechsler Memory Test from the second to sixth days of their ICU stay $(P<$ 0.001). The duration of delirium was also shorter in the xenon plus standard therapy group.

Tzigankov et al. $^{36}$ recruited 120 ICU patients who experienced acute withdrawal syndrome associated with alcohol or opioid addiction. Half of the patients received the standard therapy, which included antipsychotics, tranquilizers, vasopressors, antiplatelet agents, vitamins, glucose, and amino acids. The other half received the standard therapy in addition to $33.3 \%$ xenon inhalation three times a day for two days and one to two times a day for another three days, 10-15 min each time. Compared with standard therapy, patients in the xenon plus standard therapy group showed improvement over five to six days in their neuropsychologic assessments (e.g., memory, abstraction) and electroencephalography (duration of pathologic waves) and rheoencephalography scans (a noninvasive technique that evaluates cerebral blood flow). ${ }^{60}$

\section{Assessment of biases}

There was a wide variation of the risk of biases and Jadad scores of the included studies (see Appendix). Most studies were unable to blind the personnel to the group assignment. Some studies did not report the risk of biases.

The funnel plots of the meta-analysis on $\mathrm{S}-100 \beta$ and NSE are shown in the ESM - Supplementary Figs. 3-8. There are no asymmetric patterns suggesting publication bias.

\section{Discussion}

Despite promising pre-clinical reports, the current clinical evidence for positive neurologic and cognitive outcomes after xenon exposure is modest. Compared with therapeutic hypothermia, addition of xenon reduced cerebral white matter abnormality after out-of-hospital cardiac arrest but failed to have an impact on neurocognitive outcomes and mortality. ${ }^{34}$ In addition, in asphyxiated neonates, xenon did not provide additional benefit compared with therapeutic hypothermia. ${ }^{35}$ Compared with commonly used volatile anesthetics, xenon may improve short-term neurologic or cognitive outcomes in the early postoperative period, but evidence for long-term outcome benefits is lacking. ${ }^{38,52-55}$ The biomarkers associated with neuronal injury were also not significantly different in patients exposed to xenon compared with other commonly used volatile anesthetics. $^{38,47-50}$ To date, the only population that appears to benefit from xenon administration is patients going through substance withdrawal. ${ }^{36,37}$ Brief intermittent exposure to sub-anesthetic doses of xenon improves short-term neurocognitive outcome in the acute phase of substance withdrawal.

Xenon plus therapeutic hypothermia

It is quite surprising that in the RCTs xenon exposure conferred no added benefit to therapeutic hypothermia in asphyxiated neonates and cardiac arrest patients given the encouraging pre-clinical animal data. ${ }^{10-14,17,61,62}$ We postulate that the RCTs may not have been sufficiently powered. In the study by Azzopardi et al., ${ }^{35}$ only 92 of 138 intended subjects were recruited. Moreover, the sample size estimation was based on mortality, which has a higher incidence compared with abnormal neurologic outcome. Similarly, Laitio et al. ${ }^{34}$ powered their study to detect a change in fractional anisotropy of $15 \%$ but not to detect a change in clinical outcome. More data are needed to determine whether the negative findings of these RCTs are real or simply reflect a false-negative type 2 error.

The failure of the RCTs to show added benefit of xenon exposure to therapeutic hypothermia may also reflect fundamental errors in study design. Table 1 summarizes key study characteristics and results of the nine pre-clinical trials. All pre-clinical trials showed either additive or synergistic effects of xenon with therapeutic hypothermia when it was administered at a concentration of 50-70\% for a total duration of one to $24 \mathrm{hr}$. Moreover, xenon had a neuroprotective effect if administered within zero to two hours of the neurologic insult but the effect diminished if treatment was delayed for more than four hours. ${ }^{13,14}$ In point of fact, xenon's neuroprotective effect appeared to be dose dependent as a greater effect was observed with higher concentration $^{14}(20 \%$ vs $50 \%)$ and longer duration ${ }^{13}$ (one vs three hours) of exposure. On the other hand, in the identified RCTs, ${ }^{34,35}$ xenon was started at an average of four hours after the out-of-hospital cardiac arrest and a median of ten hours following the birth-related neonatal asphyxia. Azzopardi et al. targeted an end-tidal 


\section{S-100ß: Preoperation}

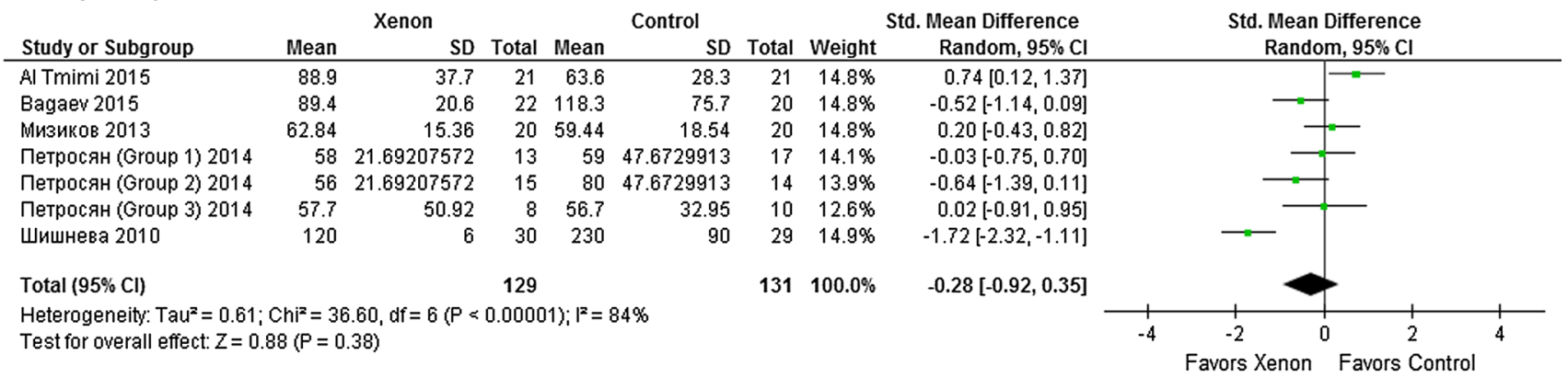

S-100ß: Immediate Postoperation

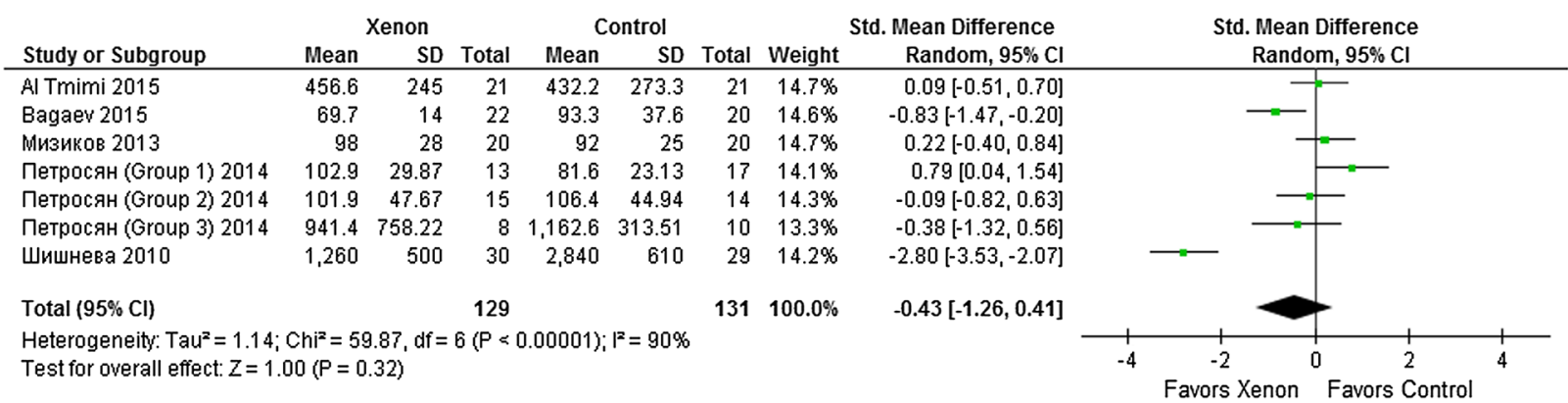

S-100ß: Postoperative Day 1

\begin{tabular}{lrrrrrrr} 
& \multicolumn{3}{c}{ Xenon } & \multicolumn{3}{c}{ Control } & \multicolumn{2}{c}{ St } \\
Study or Subgroup & Mean & SD & Total & Mean & SD & Total & Weight \\
\hline Al Tmimi 2015 & 228.8 & 113.1 & 21 & 178 & 75.4 & 21 & $18.1 \%$ \\
Мизиков 2013 & 86 & 26 & 20 & 90 & 28 & 20 & $18.1 \%$ \\
Петросян (Group 1) 2014 & 88.4 & 27.67 & 13 & 103.8 & 54.56 & 17 & $16.0 \%$ \\
Петросян (Group 2) 2014 & 86.9 & 29.65 & 15 & 106.4 & 44.94 & 14 & $15.8 \%$ \\
Петросян (Group 3) 2014 & 169.2 & 99.69 & 8 & 243.6 & 148.8 & 10 & $12.4 \%$ \\
Шишнева 2010 & 360 & 180 & 30 & 530 & 170 & 29 & $19.7 \%$ \\
& & & & & & 111 & $100.0 \%$
\end{tabular}

Heterogeneity: $\operatorname{Tau}^{2}=0.19 ; \mathrm{Ch}^{2}=13.21, \mathrm{df}=5(\mathrm{P}=0.02) ; \mathrm{I}^{2}=62 \%$

Test for overall effect: $Z=1.39(P=0.17)$

Fig. 2 Meta-analysis of S-100 $\beta$ levels (xenon $v s$ control). The confidence intervals (CI) shown in the figure are those calculated by Review Manager 5.3, which uses the Z-statistic. Adjustment according to the Satterthwaite approach; preoperation, standardized mean

concentration of only $30 \%$ based on previous clinical studies in neonates, ${ }^{35}$ while Laitio et al. did not rationalize their end-tidal concentration of approximately $48 \% .{ }^{34}$ Of note, in both these studies, a lower xenon end-tidal concentration was used compared with that in the pre-clinical studies (or, for that matter, what would normally be used during administration of general anesthesia). Although the total xenon MAC-hours administered in the two clinical studies may be theoretically adequate (xenon concentration at $30-48 \%$ for $24 \mathrm{hr}$ ), the effect of higher MAC at shorter duration may not be therapeutically equivalent to a lower MAC at a longer duration. We therefore conclude that either xenon contributes no added neurologic benefit to therapeutic hypothermia or that it may confer benefit but that it was administered too late following the neurologic insult, or at too low a dose. Future studies should take these

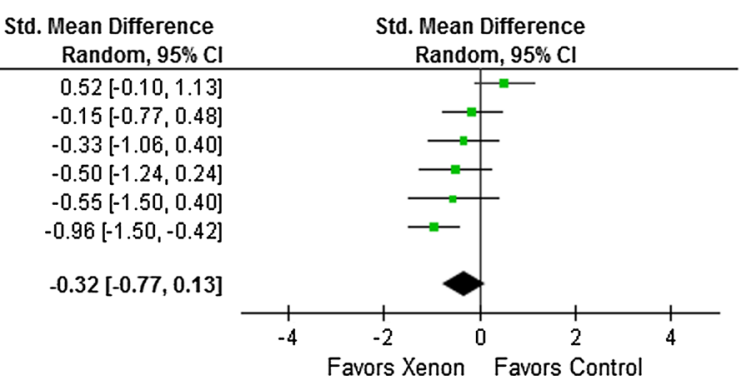

difference $(\mathrm{SMD})=-0.33(95 \% \mathrm{CI},-1.15$ to 0.49$), P=0.36$; immediate postoperation, $\mathrm{SMD}=-0.43(95 \% \mathrm{CI},-1.48$ to 0.62$), P=$ 0.36 ; postoperative day $1, \mathrm{SMD}=-0.32(95 \% \mathrm{CI},-0.91$ to 0.27$), P=$ 0.22

issues into consideration as well as the confounding variable of the severity of neurologic injury before administration of xenon and therapeutic hypothermia.

General anesthesia: postoperative delirium and cognitive dysfunction

The study by $\mathrm{Al}$ Tmimi et al. ${ }^{38}$ suggests that xenon administration may be associated with a decreased incidence of postoperative delirium compared with sevoflurane in off-pump coronary artery bypass patients. Nevertheless, this study has some noteworthy shortcomings including a relatively small number of patients randomized to either of the anesthetics and an incomplete randomization process. With other types of surgical patients in whom volatile agents were compared, xenon anesthesia was associated 
Neuron-specific enolase: Preoperation

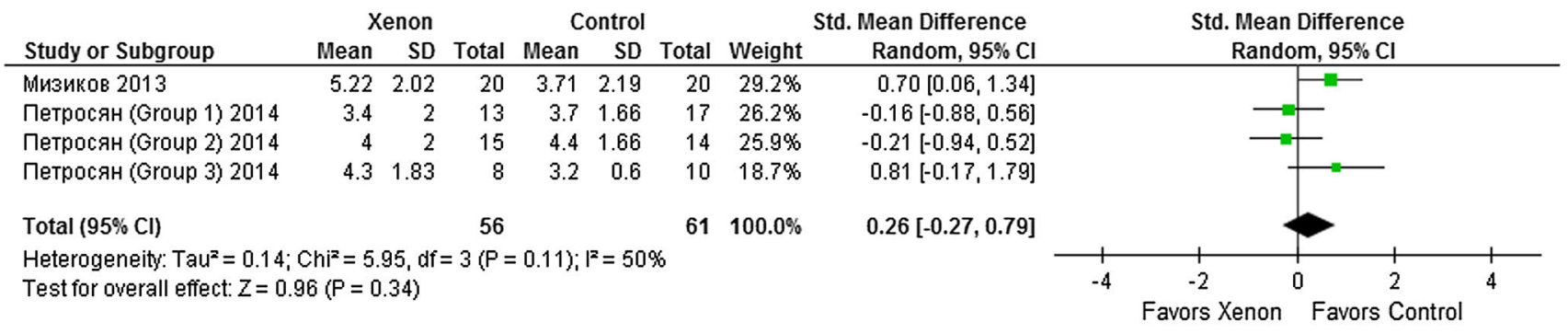

Neuron-specific enolase: Immediate Postoperation

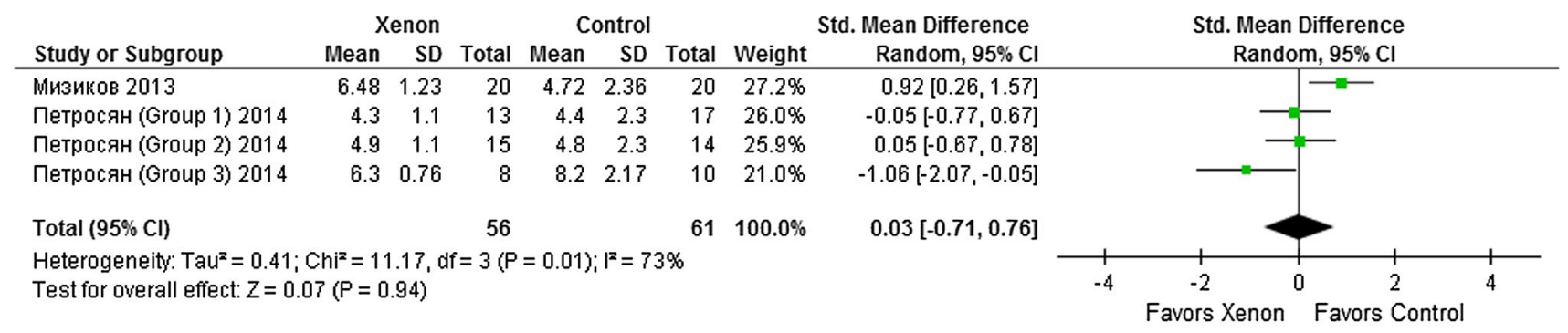

Neuron-specific enolase: Postoperative Day 1

\begin{tabular}{|c|c|c|c|c|c|c|c|}
\hline \multirow[b]{2}{*}{ Study or Subgroup } & \multicolumn{3}{|c|}{ Xenon } & \multicolumn{3}{|c|}{ Control } & \multirow[b]{2}{*}{ Weight } \\
\hline & Mean & SD & Total & Mean & SD & Total & \\
\hline Мизиков 2013 & 6.25 & 2.05 & 20 & 5.56 & 2.36 & 20 & $27.7 \%$ \\
\hline Петросян (Group 1) 2014 & 4.1 & 0.88 & 13 & 5.2 & 1.35 & 17 & $25.3 \%$ \\
\hline Петросян (Group 2) 2014 & 4 & 1.6 & 15 & 3 & 1.9 & 14 & $25.6 \%$ \\
\hline Петросян (Group 3) 2014 & 6.1 & 1.6 & 8 & 7.8 & 1.9 & 10 & $21.5 \%$ \\
\hline Total $(95 \% \mathrm{Cl})$ & & & 56 & & & 61 & $100.0 \%$ \\
\hline \multicolumn{8}{|c|}{$\begin{array}{l}\text { Heterogeneity: } \text { Tau }^{2}=0.43 ; \mathrm{Chi}^{2}=11.55, \mathrm{df}=3(P=0.009) ; I^{2}=74 \% \\
\text { Test for overall effect: } Z=0.52(P=0.60)\end{array}$} \\
\hline
\end{tabular}

Std. Mean Differenc Random, $95 \% \mathrm{Cl}$ $0.31[-0.32,0.93]$ $-0.91[-1.68,-0.15]$

$0.56[-0.19,1.30]$

$-0.91[-1.90,0.08]$

$-0.20[-0.95,0.55]$
Fig. 3 Meta-analysis of neuron-specific enolase levels (xenon versus control). The confidence intervals (CI) shown in the figure are those as calculated by Review Manager 5.3, which uses the Z-statistic. Adjustment according to the Satterthwaite approach; preoperation,

with a better recovery of cognitive functions soon (zero to three hours) after emergence from general anesthesia. ${ }^{52,55}$ Nevertheless, such benefit was not observed at later stages (six hours to three months). ${ }^{53,54}$

Most of the included studies are limited by their small sample size (18-38 patients per group). Coburns $^{39}$ and Cremer $^{54}$ initially used a $20 \%$ reduction in the attentional performance for sample size calculation but later argued that $10-15 \%$ would have been more appropriate. Rasmussen et $a .^{53}$ acknowledged that their study was not powered for cognitive outcomes and some studies may have attrition biases (e.g., Coburn ${ }^{39}$ and $\mathrm{Cremer}^{54}$ : 9/38 and $8 / 40$ patients dropped out, respectively).

The recovery of cognitive function in the early postoperative period ( $<$ three hours) can be accounted for by the rapid emergence that presumably relates to xenon's extremely low blood-gas coefficient. ${ }^{1}$ Moreover, xenon may reduce the incidence and duration of low cerebral standardized mean difference $(\mathrm{SMD})=0.26(95 \% \mathrm{CI},-0.60$ to 1.12$)$, $P=0.41$; immediate postoperation, SMD $=-0.03$ (95\% CI, -1.33 to 1.39), $P=0.95$; postoperative day $1, \mathrm{SMD}=-0.20(95 \% \mathrm{CI},-1.42$ to 1.02), $P=0.64$

saturation intraoperatively, ${ }^{58}$ which theoretically could be related to an improved postoperative cognitive function. Nevertheless, a more prolonged neurocognitive benefit would be required to stimulate further interest in using this drug as a general anesthetic. This assumes that anesthesiaassociated postoperative cognitive dysfunction proves to be a real phenomenon. ${ }^{63,64}$

Biomarkers for glial and neuronal injury after general anesthesia

S-100 $\beta$ and NSE are considered surrogate markers for damage to neural tissues. ${ }^{65-70}$ Nevertheless, S-100 $\beta$ may be a better neurologic outcome predictor than NSE because of its shorter half-life $(12 v s 48 \mathrm{hr}) .^{71}$ Both biomarkers have been correlated with neurologic outcomes in previous studies $^{72,73}$ and were proposed to predict neurologic outcomes after traumatic brain injury, to monitor on-going 
brain injury, and to assess treatment response. ${ }^{71}$ Nevertheless, our meta-analysis showed that xenon had no effect on plasma levels of either S-100 $\beta$ or NSE (Figs. 2 and 3).

The appropriateness and specificity of S-100 $\beta$ and NSE as surrogate endpoints for neurologic outcomes are still in question. Both biomarkers have extracranial sources: S$100 \beta$ is found in melanocytes, adipocytes, cardiomyocytes, and Langerhan's cells and NSE is found in erythrocytes. As such, plasma levels of these biomarkers may not accurately reflect changes originating in the CNS. There are a few additional caveats to be considered. First, none of the trials detailed the sample size calculation, making it hard to rule out a type 2 error. Second, two studies ${ }^{49,50}$ recruited patients who underwent neurosurgery, which may confound the neurologic outcomes including biomarker levels. Third, two studies ${ }^{49,50}$ compared xenon plus sevoflurane (rather than xenon alone) with sevoflurane, potentially obscuring any beneficial neurologic effect of xenon.

\section{Withdrawal from addictive substances}

Withdrawal from alcohol or opioids is associated with negative neurologic and cognitive effects, including memory, attention, and visual processing deficits, ${ }^{74-77}$ and neurologic impairment may be worse in patients requiring ICU admission. ${ }^{78,79}$ Our review indicates that in addition to standard treatment, brief intermittent inhalation of subanesthetic doses of xenon may improve neurologic and cognitive outcomes. ${ }^{36,37}$ In addition, xenon-treated patients required fewer benzodiazepines and neuroleptics. The mechanism of the effect of xenon on patients undergoing withdrawal from addiction is unclear. Possibly, xenon decreases the requirement for other sedative agents that may themselves contribute to the delirium. Alternatively, its action as an NMDA receptor antagonist might attenuate the neural excitotoxicity associated with substance-abuse withdrawal. ${ }^{80-83}$ Limitations of the studies include bias secondary to experimental design inadequacies. For instance, Tzigankov ${ }^{36}$ included patients undergoing withdrawal from opiates and alcohol in the study group, but there were only alcohol-withdrawal patients in the control group. Moreover, the processes of randomization, allocation concealment, and blinding were not explicitly reported.

\section{Safety issues}

The studies we reviewed were not specifically designed to assess safety outcome and were almost certainly underpowered to reveal relatively rare adverse effects. With these caveats in mind, the following observations can be made. In the studies concerning the addition of xenon to therapeutic hypothermia, the severe adverse event rates were similar between the experimental and control groups (e.g., death, kidney injury, seizure, cardiac arrhythmia, pneumonia, sepsis). ${ }^{34,35,51,84}$ In the studies where xenon was compared with other general anesthetic drugs in surgical patients, six of 11 studies ${ }^{39,47,48,52,54,56}$ did not mention safety outcome assessments whereas three studies $^{49,53,55}$ reported that xenon increased the risk of postoperative nausea and vomiting. With the investigations concerning patients undergoing substance-abuse withdrawal, one study ${ }^{36}$ did not observe any adverse events (details not reported in the paper) and the other ${ }^{37}$ did not report safety outcomes.

\section{Future directions}

Xenon's potential neurologic benefit has been studied in two types of patients: surgical patients (with presumably normal CNS function) and those with specific CNS-related pathophysiology (i.e., hypoxic brain injury, substance withdrawal). Xenon may confer potential benefit selectively to the latter type of patient. Future studies may reveal positive outcomes in appropriately targeted patients consistent with the promising results shown in the pre-clinical studies (Table 1). Importantly, consensus is required for the assessment of neurologic function using standardized neurocognitive assessment tools that will enable comparison of studies and the pooling of data for meta-analyses. While radiologic, electrophysiologic, and biochemical measurements provide interesting quantitative data ideally suited to such analyses, they cannot replace clinical assessment of neurologic and cognitive function. Rather, they may be considered important ancillary information that may also offer clues as to the mechanism(s) of action.

\section{Conclusions}

The current clinical evidence for the neurologic and cognitive benefits associated with the use of xenon is modest. Our review raises the possibility of a narrow therapeutic window in terms of dose, duration of therapy, delay of treatment, and type of neurologic injury. More adequately powered and appropriately designed clinical trials are needed to draw a reliable conclusion.

Conflicts of interest None declared.

Disclosures Dr. Gan has served on the Speakers Bureau for Edwards, Mallinckrodt, Medtronic and Merck.

Editorial Responsibility This submission was handled by Dr. Steven Backman, Associate Editor, Canadian Journal of Anesthesia. 
Author contributions Lawrence S.-C. Law and Elaine A.-G. Lo contributed substantially to all aspects of this manuscript, including conception and design; acquisition, analysis, and interpretation of data and drafting the article. Casper C.-C. Chan contributed substantially to the acquisition of data. Tong Joo Gan contributed substantially to the conception and design of the manuscript and the interpretation of data.

Funding Self-funding.

\section{APPENDIX Risk of bias assessment of the included randomized-controlled trials}

\begin{tabular}{|c|c|c|c|c|c|c|c|c|c|c|}
\hline \multirow[t]{2}{*}{ Author } & \multicolumn{6}{|l|}{ Risk of Bias } & \multicolumn{4}{|c|}{ Jadad Score } \\
\hline & $\begin{array}{l}\text { Adequate } \\
\text { Sequence } \\
\text { Generation }\end{array}$ & $\begin{array}{l}\text { Allocation } \\
\text { Concealment }\end{array}$ & $\begin{array}{l}\text { Blinding of } \\
\text { Participants } \\
\text { and } \\
\text { Personnel }\end{array}$ & $\begin{array}{l}\text { Blinding of } \\
\text { Outcome } \\
\text { Assessment }\end{array}$ & $\begin{array}{l}\text { Incomplete } \\
\text { Outcome } \\
\text { Data }\end{array}$ & $\begin{array}{l}\text { Selective } \\
\text { Reporting }\end{array}$ & Total & Randomization & Blinding & Attrition \\
\hline Al Tmimi $(2015)^{38}$ & Low & Low & High & Low & Low & Low & 5 & 2 & 2 & 1 \\
\hline Azzopardi $(2016)^{35}$ & Low & Low & High & Low & Low & Low & 3 & 2 & 0 & 1 \\
\hline Bagaev $(2015)^{47}$ & Unclear & Unclear & Unclear & Unclear & Low & Low & 1 & 1 & 0 & 0 \\
\hline Bronco $(2010)^{55}$ & Low & High & High & Low & Low & Low & 5 & 2 & 2 & 1 \\
\hline Coburn $(2007)^{39}$ & Low & Unclear & High & Low & High & Low & 5 & 2 & 2 & 1 \\
\hline Coburn $(2018)^{57}$ & Unclear & Unclear & Low & Low & High & High & 4 & 1 & 2 & 1 \\
\hline Devroe $(2017)^{58}$ & Low & Low & Low & High & Low & Low & 3 & 2 & 0 & 1 \\
\hline Cremer $(2011)^{54}$ & Low & Unclear & High & Low & High & High & 5 & 2 & 2 & 1 \\
\hline Laitio $(2016)^{34}$ & Low & Low & High & Low & Low & Low & 3 & 2 & 0 & 1 \\
\hline Rasmussen $(2006)^{53}$ & High & Unclear & High & Low & Low & Low & 5 & 2 & 2 & 1 \\
\hline Shishneva $(2009)^{56}$ & Unclear & Unclear & Unclear & Unclear & Low & Low & 1 & 1 & 0 & 0 \\
\hline Striepetova $(2014)^{37}$ & Unclear & Unclear & Unclear & Unclear & Low & Low & 1 & 1 & 0 & 0 \\
\hline Stuttmann $(2010)^{52}$ & Low & High & High & Low & Low & Low & 5 & 2 & 2 & 1 \\
\hline $\begin{array}{l}\text { Tzigankov } \\
\text { (Цыганков) } \\
(2013)^{36}\end{array}$ & Unclear & Unclear & Unclear & Unclear & Low & Low & 1 & 1 & 0 & 0 \\
\hline Мизиков (2013) $)^{49}$ & Unclear & Unclear & Unclear & Unclear & Low & Low & 1 & 1 & 0 & 0 \\
\hline Петросян $(2014)^{50}$ & Unclear & Unclear & Unclear & Unclear & Low & Low & 1 & 1 & 0 & 0 \\
\hline $\begin{array}{l}\text { Шишнева } \\
\text { (Shishneva) } \\
(2010)^{48}\end{array}$ & Unclear & Unclear & Unclear & Unclear & Low & Low & 1 & 1 & 0 & 0 \\
\hline
\end{tabular}

\section{References}

1. Law LS, Lo EA, Gan TJ. Xenon anesthesia: a systematic review and meta-analysis of randomized controlled trials. Anesth Analg 2016; 122: 678-97.

2. Lo EA, Law LS, Gan TJ. Paradox of the incidence of postoperative nausea and vomiting after xenon-based anaesthesia. $\mathrm{Br} \mathbf{J}$ Anaesth 2016; 116: 881-3.

3. Cattano D, Williamson P, Fukui K, et al. Potential of xenon to induce or to protect against neuroapoptosis in the developing mouse brain. Can J Anesth 2008; 55: 429-36.
4. Ma D, Williamson $P$, Januszewski A, et al. Xenon mitigates isoflurane-induced neuronal apoptosis in the developing rodent brain. Anesthesiology 2007; 106: 746-53.

5. Shu Y, Patel SM, Pac-Soo C, et al. Xenon pretreatment attenuates anesthetic-induced apoptosis in the developing brain in comparison with nitrous oxide and hypoxia. Anesthesiology 2010; 113: 360-8.

6. Cattano D, Valleggi S, Cavazzana AO, Patel CB, MA D, Giunta F. Xenon exposure in the neonatal rat brain: Effects on genes that regulate apoptosis. Minerva Anestesiol 2011; 77: 571-8.

7. Brosnan H, Bickler PE. Xenon neurotoxicity in rat hippocampal slice cultures Is Similar to Isoflurane and Sevoflurane. Anesthesiology 2013; 119: 335. 
8. Sabir H, Bishop S, Cohen N, et al. Neither xenon nor fentanyl induces neuroapoptosis in the newborn pig brain. Anesthesiology 2013; 119: 345-57.

9. Cattano D, Valleggi $S, M a D$, et al. Xenon induces transcription of ADNP in neonatal rat brain. Neurosci Lett 2008; 440: 217-21.

10. Ma D, Hossain M, Chow A, et al. Xenon and hypothermia combine to provide neuroprotection from neonatal asphyxia. Ann Neurol 2005; 58: 182-93.

11. Martin JL, Ma D, Hossain M, et al. Asynchronous administration of xenon and hypothermia significantly reduces brain infarction in the neonatal rat. Br J Anaesth 2007; 98: 236-40.

12. Hobbs C, Thoresen M, Tucker A, Aquilina K, Chakkarapani E, Dingley J. Xenon and hypothermia combine additively, offering long-term functional and histopathologic neuroprotection after neonatal hypoxia/ischemia. Stroke 2008; 39: 1307-13.

13. Thoresen M, Hobbs CE, Wood T, Chakkarapani E, Dingley J. Cooling combined with immediate or delayed xenon inhalation provides equivalent long-term neuroprotection after neonatal hypoxia-ischemia. J Cereb Blood Flow Metab 2009; 29: 707-14.

14. Sabir H, Walløe L, Dingley J, Smit E, Liu X, Thoresen M. Combined treatment of xenon and hypothermia in newborn ratsadditive or synergistic effect? PLoS One 2014; 9: e109845.

15. Schmidt M, Marx T, Glöggl E, Reinelt H, Schirmer U. Xenon attenuates cerebral damage after ischemia in pigs. Anesthesiology 2005; 102: 929-36

16. Fries $M$, Nolte $K W$, Coburn $M$, et al. Xenon reduces neurohistopathological damage and improves the early neurological deficit after cardiac arrest in pigs. Crit Care Med 2008; 36: 24206.

17. Fries $M$, Brücken A, Çizen A, et al. Combining xenon and mild therapeutic hypothermia preserves neurological function after prolonged cardiac arrest in pigs. Crit Care Med 2012; 40: 1297303.

18. Homi HM, Yokoo N, Ma D, et al. The neuroprotective effect of xenon administration during transient middle cerebral artery occlusion in mice. Anesthesiology 2003; 99: 876-81.

19. David HN, Leveille F, Chazalviel L, et al. Reduction of ischemic brain damage by nitrous oxide and xenon. J Cereb Blood Flow Metab 2003; 23: 1168-73.

20. Limatola $V$, Ward $P$, Cattano $D$, et al. Xenon preconditioning confers neuroprotection regardless of gender in a mouse model of transient middle cerebral artery occlusion. Neuroscience 2010; 165: 874-81.

21. David HN, Haelewyn B, Risso JJ. Colloc'h N, Abraini JH. Xenon is an inhibitor of tissue-plasminogen activator: adverse and beneficial effects in a rat model of thromboembolic stroke. $\mathbf{J}$ Cereb Blood Flow Metab 2010; 30: 718-28.

22. Sheng SP, Lei B, James $M L$, et al. Xenon neuroprotection in experimental stroke: interactions with hypothermia and intracerebral hemorrhage. Anesthesiology 2012; 117: 1262-75.

23. Sabir H, Osredkar D, Maes E, Wood T, Thoresen M. Xenon combined with therapeutic hypothermia is not neuroprotective after severe hypoxia-ischemia in neonatal rats. PLoS One 2016; 11: $\mathrm{e} 0156759$.

24. Coburn M, Maze M, Franks NP. The neuroprotective effects of xenon and helium in an in vitro model of traumatic brain injury. Crit Care Med 2008; 36: 588-95.

25. Harris K, Armstrong SP, Campos-Pires R, Kiru L, Franks NP, Dickinson $R$. Neuroprotection against traumatic brain injury by xenon, but not argon, is mediated by inhibition at the N-methylD-aspartate receptor glycine site. Anesthesiology 2013; 119 : 1137-48.

26. Campos-Pires R, Armstrong SP, Sebastiani A, et al. Xenon improves neurologic outcome and reduces secondary injury following trauma in an in vivo model of traumatic brain injury. Crit Care Med 2015; 43: 149-58.
27. Banks $P$, Franks $N P$, Dickinson $R$. Competitive inhibition at the glycine site of the $\mathrm{N}$-methyl-D-aspartate receptor mediates xenon neuroprotection against hypoxia-ischemia. Anesthesiology 2010; 112: 614-22.

28. Zhao H, Huang $H$, Ologunde $R$, et al. Xenon treatment protects against remote lung injury after kidney transplantation in rats. Anesthesiology 2015; 122: 1312-26.

29. Jia P, Teng J, Zou J, et al. Xenon protects against septic acute kidney injury via mir-21 target signaling pathway. Crit Care Med 2015; 43: e250-9.

30. Bantel $C$, Maze M, Trapp $S$. Neuronal preconditioning by inhalational anesthetics evidence for the role of plasmalemmal adenosine triphosphate-sensitive potassium channels. Anesthesiology 2009; 110: 986-95.

31. Bantel C, Maze M, Trapp $S$. Noble gas xenon is a novel adenosine triphosphate-sensitive potassium channel opener. Anesthesiology 2010; 112: 623-30.

32. Ma D, Lim $T, X u J$, et al. Xenon preconditioning protects against renal ischemic-reperfusion injury via HIF-1alpha activation. J Am Soc Nephrol 2009; 20: 713-20.

33. De Deken J, Rex S, Monbaliu D, Pirenne J, Jochmans I. The efficacy of noble gases in the attenuation of ischemia reperfusion injury: a systematic review and meta-analyses. Crit Care Med 2016; 44: e886-96.

34. Laitio $R$, Hynninen $M$, Arola $O$, et al. Effect of inhaled xenon on cerebral white matter damage in comatose survivors of out-ofhospital cardiac arrest: a randomized clinical trial. JAMA 2016; 315: 1120-8.

35. Azzopardi D, Robertson NJ, Bainbridge A, et al. Moderate hypothermia within $6 \mathrm{~h}$ of birth plus inhaled xenon versus moderate hypothermia alone after birth asphyxia (TOBY-Xe): a proof-of-concept, open-label, randomised controlled trial. Lancet Neurol 2016; 15: 145-53.

36. Цыганков БД, Шамов СА, Рыхлеикий П, Давлетов ЛА. ВОЗМОЖНОСТИ ПРИМЕНЕНИЯ КСЕНОНА В КОМПЛЕКСНОЙ ТЕРАПИИ ПСИХОПАТОЛОГИЧЕСКИХ РАССТРОЙСТВ У БОЛЬНЫХ НАРКОЛОГИЧЕСКОГО ПРОФИЛЯ. РОсСИЙскИЙ медицинский журнал 2013; 2013: 11-3.

37. Striepetova $O V$. Successful experience of xenon application in the complex of intensive care for alcohol use disorders. Медицина неотложных состояний 2014; 7: 88-94.

38. Al Tmimi L, Van Hemelrijck J, Van De Velde $M$, et al. Xenon anaesthesia for patients undergoing off-pump coronary artery bypass graft surgery: a prospective randomized controlled pilot trial. Br J Anaesth 2015; 115: 550-9.

39. Coburn M, Baumert JH, Roertgen D, et al. Emergence and early cognitive function in the elderly after xenon or desflurane anaesthesia: a double-blinded randomized controlled trial. $\mathrm{Br} \mathrm{J}$ Anaesth 2007; 98: 756-62.

40. Liberati A, Altman DG, Tetzlaff $J$, et al. The PRISMA statement for reporting systematic reviews and meta-analyses of studies that evaluate health care interventions: explanation and elaboration. $\mathbf{J}$ Clin Epidemiol 2009; 62: e1-34.

41. Maze M, Pirracchio $R$. Will xenon be a valuable addition in perioperative and critical care settings? Anesth Analg 2016; 122: 593-6.

42. Olivo SA, Macedo LG, Gadotti IC, Fuentes J, Stanton T, Magee $D J$. Scales to assess the quality of randomized controlled trials: a systematic review. Phys Ther 2008; 88: 156-75.

43. Higgins JP, Green $S$. Cochrane Handbook for Systematic Reviews of Interventions Version 5.1.0 (updated March 2011). Cochrane Collaboration 2011. Available from URL: http://handbook-5-1.cochrane.org/ (accessed April 2018).

44. Schünemann H, Brożek J, Guyatt G, Oxman A. GRADE Handbook. Grading of Recommendations, Assessment, Development and Evaluations (GRADE) Working Group; 2013. Available 
from URL: http://gdt.guidelinedevelopment.org/app/handbook/ handbook.html (accessed April 2018).

45. Takeshima N, Sozu T, Tajika A, Ogawa Y, Hayasaka Y, Furukawa $T A$. Which is more generalizable, powerful and interpretable in meta-analyses, mean difference or standardized mean difference? BMC Med Res Methodol 2014; 14: 30.

46. Ledolter J, Dexter F. Analysis of interventions influencing or reducing patient waiting while stratifying by surgical procedure 2011; 112: 950-7.

47. Bagaev VG, Arsen'yeva EN, Luk'yanov VI, Bykov MV, Amcheslavskiy $V G$. The study of neuro-toxicity under application of modern anesthesia agents. ЛЕЧЕНИЕ и ПРОФИЛАКТИКА 2015; $1: 22-6$.

48. Е.В. Шишнева, Подоксенов ЮК, Емельянова ТВ, Шипулин $B M$, Лебедева $E B$. ОПТИМИЗАЦИЯ ЗАЩИТЫ ГОЛОВНОГО МОЗГА ПУТЕМ ПРИМЕНЕНИЯ МЕТОДИКИ ГИПОКСИЧЕСКОГО ПРЕКОНДИЦИОНИРОВАНИЯ И АНЕСТЕЗИИ КСЕНОНОМ У КАРДИОХИРУРГИЧЕСКИХ ПАЦИЕНТОВ. Патология кровообращения и кардиохирургия 2010; 2010: 40-4.

49. Мизиков ВМ, Вяткин АА, Петросян ЛГ, Винниикий ЛИ, Самохина ЛО. Комбинированная анестезия на основе ксенона и оценка возможности ее применения как метода нейропротективного воздействия при внутричерепных операциях. ИНФОРМАЦИЯ О ПУБЛИКАЦИИ 2013; 1: 58-69.

50. Grantovna PL. Evaluation of xenon's neuroprotective properties in the Surgery of patients with space-occupying lesions of the brain [Internet]. Russian Academy of Medical Sciences; 2014. Available from URL: http://xn-90ax2c.xn-p1ai/catalog/000199_0 00009_005098597/.

51. Arola OJ, Laitio RM, Roine RO, et al. Feasibility and cardiac safety of inhaled xenon in combination with therapeutic hypothermia following out-of-hospital cardiac arrest. Crit Care Med 2013; 41: 2116-24.

52. Stuttmann $R$, Jakubetz J, Schultz $K$, et al. Recovery index, attentiveness and state of memory after xenon or isoflurane anaesthesia: a randomized controlled trial. BMC Anesthesiol 2010; 10: 5 .

53. Rasmussen LS, Schmehl W, Jakobsson J. Comparison of xenon with propofol for supplementary general anaesthesia for knee replacement: a randomized study. Br J Anaesth 2006; 97: 154-9.

54. Cremer J, Stoppe C, Fahlenkamp AV, et al. Early cognitive function, recovery and well-being after sevoflurane and xenon anaesthesia in the elderly: a double-blinded randomized controlled trial. Med Gas Res 2011; 1: 9.

55. Bronco A, Ingelmo PM, Aprigliano $M$, et al. Xenon anaesthesia produces better early postoperative cognitive recovery than sevoflurane anaesthesia. Eur J Anaesthesiol 2010; 27: 912-6.

56. Shishneva $Y V$, Podoxenov YK, Yemelyanova TV, Shipoulin VM. Aggressive factors of extracorporeal blood flow: cerebral injury and optimization of its defense ways. Сибирский медицинский журнал 2009; 24: 103-16.

57. Coburn M, Sanders RD, Maze M, et al. The hip fracture surgery in elderly patients (HIPELD) study to evaluate xenon anaesthesia for the prevention of postoperative delirium : a multicentre, randomized clinical trial. Br J Anaesth 2018; 120: 127-37.

58. Devroe $S$, Meeusen R, Gewillig $M$, et al. Xenon as an adjuvant to sevoflurane anesthesia in children younger than 4 years of age, undergoing interventional or diagnostic cardiac catheterization: a randomized controlled clinical trial. Paediatr Anaesth 2017; 27: 1210-9.

59. Luyt CE, Galanaud D, Perlbarg V, et al. Diffusion tensor imaging to predict long-term outcome after cardiac arrest: a bicentric pilot study. Anesthesiology 2012; 117: 1311-21.

60. Hadjiev $D$. A new method for quantitative evaluation of cerebral blood flow by rheoencephalography. Brain Res 1968; 8: 213-5.
61. Faulkner S, Bainbridge A, Kato $T$, et al. Xenon augmented hypothermia reduces early lactate/ $\mathrm{N}$-acetylaspartate and cell death in perinatal asphyxia. Ann Neurol 2011; 70: 133-50.

62. Chakkarapani E, Dingley J, Liu X, et al. Xenon enhances hypothermic neuroprotection in asphyxiated newborn pigs. Ann Neurol 2010; 68: 330-41.

63. Dokkedal U, Hansen TG, Rasmussen LS, Mengel-From J, Christensen $K$. Cognitive functioning after surgery in middleaged and elderly danish twins. Anesthesiology 2016; 124: 31221.

64. Bartels $M$, Althoff RR, Boomsma DI. Anesthesia and cognitive performance in children: no evidence for a causal relationship. Twin Res Hum Genet 2009; 12: 246-53.

65. Martens P, Raabe A, Johnsson P. Serum S-100 and neuronspecific enolase for prediction of regaining consciousness after global cerebral ischemia. Stroke 1998; 29: 2363-6.

66. Al Tmimi L, Van de Velde M, Meyns B, et al. Serum protein S100 as marker of postoperative delirium after off-pump coronary artery bypass surgery: secondary analysis of two prospective randomized controlled trials. Clin Chem Lab Med 2016; 54: 1671-80.

67. Rodríguez-Rodríguez A, Egea-Guerrero JJ, Gordillo-Escobar E, et al. S100B and neuron-specific enolase as mortality predictors in patients with severe traumatic brain injury. Neurol Res 2016; 38: $130-7$.

68. Fogel $W$, Krieger D, Veith $M$, et al. Serum neuron-specific enolase as early predictor of outcome after cardiac arrest. Crit Care Med 1997; 25: 1133-8.

69. Rech TH, Vieira SRR, Nagel F, Brauner JS, Scalco R. Serum neuron-specific enolase as early predictor of outcome after inhospital cardiac arrest: a cohort study. Crit Care 2006; 10: R133.

70. Daubin C, Quentin C, Allouche $S$, et al. Serum neuron-specific enolase as predictor of outcome in comatose cardiac-arrest survivors: a prospective cohort study. BMC Cardiovasc Disord 2011; 11: 48.

71. Thelin EP, Nelson DW, Bellander B. A review of the clinical utility of serum S100B protein levels in the assessment of traumatic brain injury. Acta Neurochir (Wien) 2017; 159: 209-25.

72. Silva FP, Schmidt AP, Valentin LS, et al. S100B protein and neuron-specific enolase as predictors of cognitive dysfunction after coronary artery bypass graft surgery: a prospective observational study. Eur J Anaesthesiol 2016; 33: 681-9.

73. Shinozaki K, Oda S, Sadahiro T, et al. S-100B and neuron-specific enolase as predictors of neurological outcome in patients after cardiac arrest and return of spontaneous circulation: a systematic review. Crit Care 2009; 13: R121.

74. Kelley BJ, Yeager KR, Pepper TH, Beversdorf DQ. Cognitive impairment in acute cocaine withdrawal. Cogn Behav Neurol 2005; 18: 108-12.

75. Seifert J, Seeland I, Borsutzky M, et al. Effects of acute alcohol withdrawal on memory performance in alcohol-dependent patients: a pilot study. Addict Biol 2003; 8: 75-80.

76. Loeber S, Duka T, Welzel Márquez H, et al. Effects of repeated withdrawal from alcohol on recovery of cognitive impairment under abstinence and rate of relapse. Alcohol Alcohol 2010; 45: 541-7.

77. Lyvers $M$, Yakimoff $M$. Neuropsychological correlates of opioid dependence and withdrawal. Addict Behav 2003; 28: 605-11.

78. Sarff M, Gold JA. Alcohol withdrawal syndromes in the intensive care unit. Crit Care Med 2010; 38: S494-501.

79. Spies CD, Dubisz N, Neumann T, et al. Therapy of alcohol withdrawal syndrome in intensive care unit patients following trauma: results of a prospective, randomized trial. Crit Care Med 1996; 24: 414-22.

80. Veatch LM, Becker HC. Lorazepam and MK-801 effects on behavioral and electrographic indices of alcohol withdrawal sensitization. Brain Res 2005; 1065: 92-106. 
81. Thomas JD, Weinert SP, Sharif S, Riley EP. MK-801 administration during ethanol withdrawal in neonatal rat pups attenuates ethanol-induced behavioral deficits. Alcohol Clin Exp Res 1997; 21: $1218-25$.

82. Reynolds AR, Berry JN, Sharrett-Field L, Prendergast MA. Ethanol withdrawal is required to produce persisting N-methylD-aspartate receptor-dependent hippocampal cytotoxicity during chronic intermittent ethanol exposure. Alcohol 2015; 49: 219-27.
83. Nelson TE, Ur CL, Gruol DL. Chronic intermittent ethanol exposure enhances NMDA-receptor-mediated synaptic responses and NMDA receptor expression in hippocampal CA1 region. Brain Res 2005; 1048: 69-79.

84. Dingley J, Tooley J, Liu X, et al. Xenon ventilation during therapeutic hypothermia in neonatal encephalopathy: a feasibility study. Pediatrics 2014; 133: 809-18. 